\title{
Scrutinizing the Impact of Teachers' Critical Thinking and Teaching Autonomy on Their Teaching Success and Learners' Use of Language Learning Strategies
}

\author{
Mania Nosratinia \\ Islamic Azad University at Central Tehran, Iran
}

Alireza Zaker
Young Researchers and Elites Club, Islamic Azad University, Science and Research Branch, Tehran, Iran

\begin{abstract}
Postmethod perspective on English as a Foreign Language (EFL) teaching considers EFL teachers to be reflective and autonomous practitioners who play the role of change agents. In order to systematically study the way these attributes affect teachers' and learners' actual performance, this study investigated the effect of EFL teachers' Critical Thinking (CT) and Teaching Autonomy (TA) on their Teaching Success (TS) and EFL learners' Language Learning Strategies (LLS) use. Twenty mixed-gender upper-intermediate and advanced level general English classes were randomly selected from ten language schools. The teachers were 25 to 40 years of age $\left(M_{\text {age }}=31\right)$, whereas the learners were 18 to $30\left(M_{\text {age }}=24\right)$. In each class, $C T$ and TA questionnaires were answered by the teacher and the LLS and TS scales were completed by the learners after 12 to 19 sessions. The results of a one-way ANOVA followed by a post-hoc Scheffe's revealed that those EFL learners whose teachers had a high TA level show a significantly higher perception toward TS. Moreover, those learners whose teachers had a low CT level showed a higher, but non-significant, perception toward TS. Furthermore, EFL learners whose teachers had a moderate level of TA demonstrated a higher, but nonsignificant, use of LLS. Finally, EFL learners whose teachers had a high CT level showed a higher, but nonsignificant use of LLS. Regarding the limitations and drawing upon the findings, the article concludes with some pedagogical implications and some avenues for future research.
\end{abstract}

Index Terms — critical thinking, language learning strategies, teaching autonomy, teaching success

\section{INTRODUCTION}

Current trends in Teaching English as a Foreign Language (TEFL), like those favored by Postmethod methodology, are founded upon the notion that English as a Foreign Language (EFL) teachers function as transformative intellectuals and reflective practitioners (Kumaravadivelu, 2012). They are expected to play the role of change agents and raise educational, social, cultural, and political consciousness in their learners (Kumaravadivelu, 2012). Moreover, it is believed that EFL teachers have a significance influence over many of the internal factors among EFL learners (Nosratinia \& Zaker, 2014, 2015; Zaker, 2013, 2015, 2016).

Taking on the role of reflective practitioners and employing the intellectual ability to reflectively cogitate on the practice of teaching, according to Farrell (2012), are now considered to be among the essential needs for language educators which will happen through a critical analysis of the teaching and learning attitudes and practices so that educators will function more autonomously and responsibly (Farrell, 2012). This new perspective seems to be inconsistent with the conventional beliefs which consider the role of EFL teachers to transmit knowledge from the curriculum to the learners (Bell, 2003; Kumaravadivelu, 2001).

The way EFL teachers function, just like every human being, is substantially influenced by their internal, mental, cognitive, and metacognitive factors. Accordingly, it is now widely believed that EFL teachers' mental traits, to a large extent, predict and determine how they attempt to materialize the pedagogical goals (Borg, 2006; Freeman, 2002). In a similar vein, Lange (1990) favors the idea that there exists an intimate relationship between critically reflecting on the practice of teaching and the process of teacher development. Lange (1990) has remarked:

The reflective process allows developing teachers latitude to experiment within a framework of growing knowledge and experience. It gives them the opportunity to examine their relations with students, their values, their abilities, and their successes and failures in a realistic context. It begins the developing teacher's path toward becoming an "expert teacher." (p. 249-250)

It seems, therefore, quite reasonable to state that any attempt to develop the TEFL practice should acknowledge EFL teachers' internal factors as highly influential factors which substantially affect the way they perform in the classroom 
(Garton, 2008). In actual fact, the building blocks of the teachers' internal framework of teaching are influenced by both research and teachers' reflection and observation of teaching and learning (Nation \& Macalister, 2010).

Assuming reflective practice as an integral component of teaching practice, Farrell (2012) sensibly argues that if teaching is not interwoven with consciously reflecting on the practice, the routine and mechanically repetitive actions can lead to eventual burnout and losing the internal motiving force. This premise seems to be in line with Dewey's (1933) argument where he maintains that teachers who do not bother to reflect on their work are bound to become slaves to routine. As Richards and Lockhart (1994) put it, teachers should "collect data about their teaching, examine their attitudes, beliefs, assumptions, and teaching practices, and use the information obtained as a basis for critical reflection about teaching" (p. 1).

Teaching is a reflective activity which at once shapes and is shaped by the doing and theorizing based on reflection and acting autonomously based on a self-made and context-sensitive theory of teaching (Kumaravadivelu, 2012). Edge (2001) states that, "the thinking teacher is no longer perceived as someone who applies theories, but someone who theorizes practice" (p. 6). Based on the abovementioned points, critical reflection on the practice of teaching seems to be one of the fundamental elements when it comes to equipping EFL teachers with a heightened degree of knowledge, recognizing their personal agency, and, as Akbari (2008) puts it, legitimizing their voices. This personal agency later presents itself as the ability to act more autonomously and flexibly in different contexts based on the internalized teaching knowledge (Farrell, 2012; Kumaravadivelu, 2008).

The proposed notion of theorizing from practice and reflective teaching can only become materialized when the EFL teacher acts based on their own agency and theory of teaching which can be called autonomous practice (Paul \& Elder, 2008; Scharle \& Szabo, 2000). Autonomy (AU), as defined by Little (1991), is "[a] capacity - for detachment, critical reflection, decision-making, and independent action" (p. 4). An autonomous individual is not dependant on others for the direction and control of one's thinking (Paul \& Elder, 2008). Teaching autonomy, therefore, seems to trace its roots to acknowledging EFL practitioners' potential to know both how to teach and how to act autonomously based on the personalized theory within the academic and administrative constraints. Therefore, there seems to be an absolute requirement for integration of these two elements for a well-informed, context-sensitive, and personalized practice of teaching.

As stated above, EFL practitioners are expected to be reflective, autonomous, and transformative intellectuals who play the role of change agents and act on information about learners, context, and pedagogical goals (Farrell, 2012; Kumaravadivelu, 2012; Richards \& Lockhart, 1994). The underlying basis of this view seems to be promoting language learning and teaching success through encouraging EFL teachers' reflective and autonomous performance. This is based on the belief that teacher quality is a crucial predictor of students' performance (King, 2003).

Based on the arguments put forward, there should be a significant relationship between EFL teachers' degree of critical reflection and autonomous act, on the one hand, and EFL learners' performance, on the other hand. EFL learners' performance can be evaluated through different measures, e.g. language development, language learning techniques, and overall satisfaction with the instruction. Therefore, in order to systematically inspect the way the abovementioned teachers factors, i.e. reflection on practice and autonomous performance, can affect EFL teachers' success in teaching and the way EFL learners are influenced, this study particularly attempts to investigate the effect of EFL teachers' Critical Thinking (CT) and Teaching Autonomy (TA) on their Teaching Success (TS) as perceived by EFL learners and Language Learning Strategies (LLS) use which is believed to directly affect the process of learning a second language (Green \& Oxford, 1995; Griffiths, 2007; O'Maley \& Chamot, 1990). Figure 1 presents a schematic overview of the variables of this study.

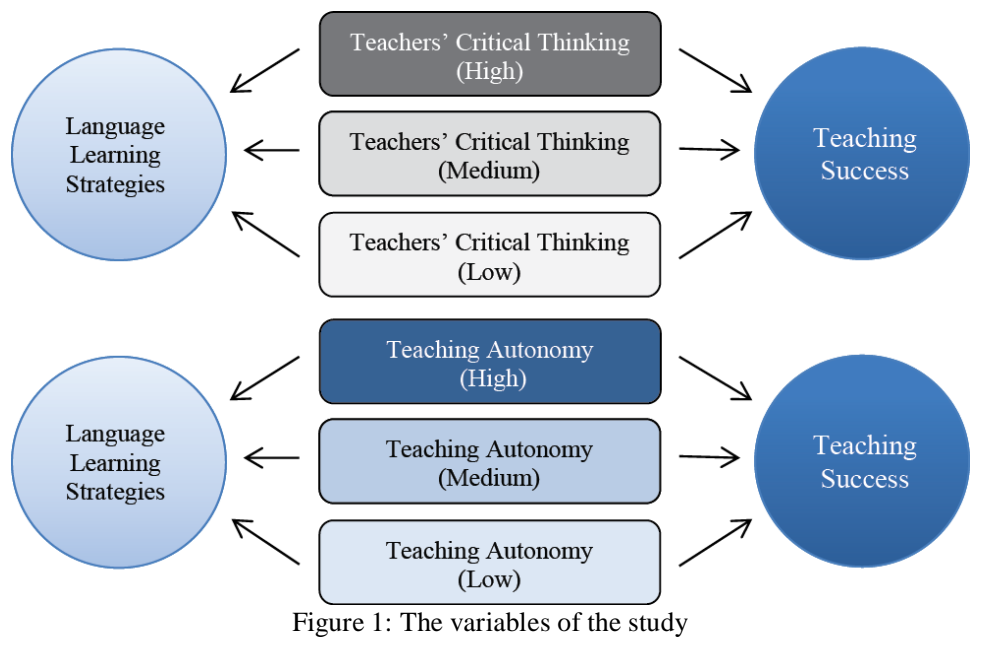

Teaching success can be defined as a multifaceted phenomenon which brings about realizing pedagogical goals, effective learning, and learning-experience satisfaction among learners (Haskvitz, 2007). However, different views have 
been presented about teaching success. Elizabeth, May and Chee (2008) report the results of their meta-analysis of studies on teacher effectiveness, asserting that on top of distinctive personality traits, effective teachers are distinguished by strong cognitive skills. Regarding successful teachers, they further argue that:

They are subject specialists who are able to select, organize, and deliver content, are efficient and effective in the use of instructional time, and are able to vary their teaching strategies according to student needs... [They] are skilful in using questions, promote critical and creative thinking, and use wait time when seeking student response. (p. 624)

The investigation of teacher success is important as with better knowledge of the concept, educators can better envisage professional development directions, and enhance the quality of teacher education programs. Tamblyn (2000) has identified seven qualities of successful teachers, most of which focus on teachers' personality features and attitudes. These qualities are:

- subject competence;

- skill in motivating learners through positive reinforcement;

- flexibility and expertise in adapting the materials to the students' needs;

- willingness to take risks and make mistakes;

- respect for learners;

- warmth, a caring attitude, and a sense of humor; \&

- self-esteem, satisfaction with the profession, and a willingness to go the extra mile.

As stated earlier, there is a unanimous consensus that teachers' characteristics can affect learners' performance, especially their cognitive abilities and mental processes employed during learning. These mental peculiarities play a central role in the process of learning (Fahim \& Zaker, 2014; Griffiths, 2007; Nosratinia, Abbasi, \& Zaker, 2015; Nosratinia, Saveiy, \& Zaker, 2014; Nosratinia, Shakoori, \& Zaker, 2013; Nosratinia \& Zaker, 2013, 2014, 2015; Nosratinia, Zaker, \& Saveiy, 2015). Language learning strategies, as one of these metacognitive factors, can be defined as those attempts made by language learners intended to facilitate the process of learning during second language learning (Oxford, 1990; Wenden, 1991). They are tools for the self-directed involvement necessary for developing language skills (Oxford, 1990). Regarding the interaction between EFL teachers' performance and EFL learners' learning process, Oxford (1990) further adds that, "[T]eachers try to help learners develop the concept that learning is a lifetime process, and learners need to be equipped with "self-directed learning skills"(p. 8). Thus, one might argue that LLS should be emphasized in EFL classroom in order to make learning easier, more effective, and fruitful.

EFL teachers are expected to function as transformative intellectuals and reflective practitioners (Kumaravadivelu, 2012) which enables them to have a significance influence over the process of learning as well as many of the internal factors among EFL learners (King, 2003; Nosratinia \& Zaker, 2014). Based on this hypothesis and the points discussed above, the following research questions were proposed:

Research Question 1: Does EFL teachers' TA level have any significant effect on EFL learners' perceived TS?

Research Question 2: Does EFL teachers' CT level have any significant effect on EFL learners 'perceived TS?

Research Question 3: Does EFL teachers' TA level have any significant effect on EFL learners' use of LLS?

Research Question 4: Does EFL teachers' CT level have any significant effect on EFL learners' use of LLS?

\section{METHOD}

\section{Participants}

The participants of this study consisted of both EFL teachers and EFL learners. Twenty mixed-gender upperintermediate and advanced level general English classes, as stated by the language schools, were randomly selected from ten language schools in Tehran. In these classes, different course books were used which covered all the four skills of listening, reading, writing, and speaking. Moreover, group work, cooperative learning, and equal participation of learners were among the main concerns of the teachers.

English was the main medium of instruction in these classes; however, occasional use of learners' first language (L1; Persian) was tolerated. The EFL teachers $\left(\mathrm{n}=20,13\right.$ females, $65 \%$, and 7 males, 35\%) were 25 to 40 years of age $\left(M_{\text {age }}\right.$ $=31)$, whereas the learners $\left(\mathrm{n}=199,124\right.$ females, 62\%, and 75 males, 38\%) were 18 to $30\left(\mathrm{M}_{\mathrm{age}}=24\right)$. The number of EFL learners in each class ranged from 7 to $12(\mathrm{M}=10)$.

\section{Instrumentation}

In order to carry through the purpose of the study, the following four instruments utilized in order to collect the data pertaining to the participants' CT, TA, TS, and LLS:

1. A questionnaire of CT developed by Honey (2000) for EFL teachers;

2. A questionnaire of TA developed by Pearson and Hall (1993) for EFL teachers;

3. A questionnaire of LLS designed by Oxford (1990) for EFL learners; and

4. A questionnaire of TS designed by Moafian and Pishghadam (2009) for EFL learners.

\section{CT Questionnaire}

The CT Questionnaire intends to inspect what a person might or might not do when thinking critically about a subject. Developed by Honey (2000), the questionnaire aims at evaluating the three main skills of comprehension, analysis, and evaluation. This Likert-type questionnaire has 30 items which makes it possible to investigate individuals' ability in 
note-taking, summarizing, questioning, paraphrasing, researching, inferencing, discussing, classifying and outlining, comparing and contrasting, distinguishing, synthesizing, and inductive and deductive reasoning.

EFL teachers were asked to rate the frequency of each category they use on a 5-point Likert scale, ranging from never ( 1 point), seldom ( 2 points), sometimes ( 3 points), often ( 4 points), to always ( 5 points). The final scores are calculated by adding up the numbers of the scores, and the ultimate score is computed in the possible range of 30 to150. The participants were allocated 20 minutes to complete this questionnaire.

In this study, the Persian version of this questionnaire was employed which was translated and validated by Naeini (2005). In a study conducted by Nosratinia and Zaker (2014), the reliability of this questionnaire was estimated to be 0.81 using Cronbach's alpha coefficient. In this study, the reliability of CT questionnaire was estimated to be 0.69 using Cronbach's alpha coefficient.

\section{TA Questionnaire}

TA scale was developed by Pearson and Hall (1993). This questionnaire consists of 18 items, and participants are asked to rate the statements on a 5-point Likert scale, ranging from definitely true (4 points), more or less true (3 points), more or less false ( 2 points), to definitely false ( 1 point); therefore, the total scores are calculated within the range of 18 to 72 . EFL teachers were allocated 10 minutes to complete the questionnaire.

Pearson and Hall (1993) reported that the questionnaire has an internal consistency of 0.80 employing Cronbach's alpha with two factors: curriculum autonomy and general teaching autonomy ( 7 and 11 items, respectively). In this study, the reliability of TA questionnaire was estimated to be 0.71 using Cronbach's alpha coefficient.

\section{TS Questionnaire}

To estimate the degree of teachers' success through students' evaluation, a 47-item questionnaire on characteristics of successful Iranian EFL teachers, by Moafian and Pishghadam (2009) was employed. This questionnaire investigates teaching success through inspecting the 12 subcomponents which are termed: accountability, interpersonal relationships, attention to all, examination, commitment, learning boosters, creating a sense of competence, teaching boosters, physical and emotional acceptance, empathy, class attendance, and dynamism.

EFL learners were asked to choose between options on a 5-point Likert scale, ranging from strongly disagree (1 point), disagree ( 2 points), partially agree ( 3 points), agree ( 4 points), to strongly agree ( 5 points). The participants (EFL learners) were allocated 30 minutes to complete the questionnaire, and the ultimate scores were computed in the possible range of 47 to 235 . In this study, the reliability of TS questionnaire was estimated to be 0.67 using Cronbach's alpha coefficient.

\section{LLS Questionnaire}

Strategy Inventory for Language Learning (SILL) was developed by Oxford (1990). Two versions of the SILL are presented in Oxford (1990). The first version is designed for foreign language learners whose native language is English, including 80 items. The second version, employed in this study, is designed for EFL learners, including 50 items.

The inventory is divided into 6 parts, which shows different kinds of strategies. The first part (memory strategies) includes 9 items, the second part (cognitive strategies) contains 14 items, the third part (compensation strategies) consists of 6 items, the fourth part (metacognitive strategies) includes 9 items and the fifth and the sixth parts (affective strategies and social strategies) each consists of 6 items. The 50 statements in the inventory follow the general format "I do such and such" and participants respond on 5 Likert scale, ranging from 1 "Never or almost never true of me" to 5 "Always or almost always true of me". The EFL learners were given 30 minutes to complete this questionnaire.

According to Ehrman and Oxford (1990), SILL has consistently scored above 0.90 using Cronbach's alpha which indicates high internal reliability. Oxford (1996) reported Cronbach's alpha of 0.96 for SILL. In this study, the reliability of LLS questionnaire was estimated to be 0.61 using Cronbach's alpha coefficient.

\section{Procedure}

To achieve the purpose of the study and address the questions posed, certain procedures were pursued which are explained below.

After obtaining a formal approval for conducting this research in the language schools mentioned above (see participants), one class was randomly chosen from three available classes and the other two classes were excluded from the study. This procedure was followed in order to select the participants on a cluster sampling basis which would increase the validity and generalizability of the findings of a descriptive study, in this case an ex post facto study (Best \& Kahn, 2006; Springer, 2010). It should be mentioned that due to the nature of this descriptive study, no criterion for establishing homogeneity was adopted.

The number of EFL learners in the randomly selected classes $(n=20)$ ranged from 7 to $12(M=10)$. Each selected classroom had one EFL teacher (Total $=20$ ) who attended the class for the whole semester. All EFL students and teachers in the selected class were informed about the aim of the study and were given the choice whether to fill in the questionnaires or not. They were also informed that the information supplied by them will be treated as confidential.

EFL teachers were informed and reasonably convinced that the results of the questionnaires and their answers will never be shared with the language schools, their colleagues, and the students. EFL learners were also informed that the results of this survey would by no means exert influence on their course scores and the results would be handled with confidentiality. This information was provided in order to encourage the participants to supply more accurate answers 
which would eventually increase the validity and generalizability of the findings of the study (Best \& Kahn, 2006; Mackey \& Gass; 2005; Springer, 2010).

After obtaining an informed consent and before administrating the questionnaires, the participants were fully briefed on the process of completing the questionnaires; this briefing was given by one of the researchers in participants' L1 through explaining and exemplifying the process of choosing the answers. EFL teachers were given 30 minutes to complete the CT and TA questionnaires, with no specific priority about the time of completion, i.e. the questionnaires could be completed at any time during the course. Following this, the LLS and TS scales were completed by EFL learners after 12 to $19(\mathrm{M}=15)$ sessions of attending the English class being instructed by the teacher participating in the study. The allocated time for EFL learners was 60 minutes. The researchers intentionally randomized the order of questionnaires administered to control the impact of order upon the completion process and validity of the data, and all of the questionnaires completed by EFL learners were administered and returned in one session.

The researchers randomly observed the process of filling out for some individuals to make sure they were capable to fully understand the questions and responses. Moreover, some of the participants were interviewed to see if there are other factors affecting their answers. Subsequently, the administrated questionnaires were scored and the statistical analyses of this ex post facto study were carried out whose results are elaborated in the following sections.

It is worth mentioning here that out of the initial 26 randomly selected classes, 20 of the EFL teachers agreed to participate in the study. Moreover, some of the learners in each class did not participate in the study. Therefore, the number of participants in this study came to 20 EFL teachers and 199 of their students.

\section{RESULTS}

\section{Preliminary Analyses}

This study aimed at investigating the effect of teachers' CT and TA on their TS, as perceived by EFL learners, and EFL learners' LLS. As stated above, the design of this study is ex post facto. Therefore, to achieve the desired goals, EFL teachers' total scores on CT and TA were converted into three levels of high, moderate, and low. As displayed in Table 1, CT scores have a mean of 107.82 and a standard deviation of 15.85. Accordingly, those teachers whose CT scores fell half a standard deviation below the mean, i.e. 99.9 and lower, were put into the low CT category. On the other hand, EFL teachers whose CT scores fell half a standard deviation above the mean, i.e. 115.75 and higher, were put into the high CT level. The rest of teachers, in between, formed the moderate CT group.

TABLE 1:

DESCRIPTIVE STATISTICS OF TEACHERS' CRITICAL THINKING

\begin{tabular}{lllll}
\hline & Minimum & Maximum & Mean & Std. Deviation \\
\hline Critical Thinking & 84 & 136 & 107.82 & 15.848 \\
\hline
\end{tabular}

The same procedure was employed to divide EFL teachers into three groups based on their TA scores. Using the information reported in Table 2, EFL teachers whose TA scores fell half a standard deviation below the mean, i.e. 44.22 and lower, were put into the low TA category. On the other hand, EFL teachers whose TA scores fell half a standard deviation above the mean, i.e. 52.26 and higher, were put into the high TA category, and the rest of teachers formed the moderate TA group.

TABLE 2:

DESCRIPTIVE STATISTICS OF TEACHING AUTONOMY

\begin{tabular}{lllll}
\hline & Minimum & Maximum & Mean & Std. Deviation \\
\hline Teacher Autonomy & 31 & 64 & 48.24 & 8.036 \\
\hline
\end{tabular}

\section{Testing Assumptions}

The assumptions of interval data, independence of subjects, normality, and homogeneity of variances were needed to be met before running parametric tests in order to answer the research questions raised in this study (Creswell, 2012; Lodico, Spaulding, \& Voegtle, 2010). The present data were measured on an interval scale, and the subjects were independent of one another; put another way, their performance on the tests was not affected by the performance of other participants. Moreover, the present data enjoyed normal distributions across the three levels of teachers CT and TA. Furthermore, all of the values of skewness and kurtosis ratio fell within the ranges of \pm 1.96 ; therefore, it could be argued that the data met the assumption of normality.

The assumption of homogeneity of variances is not discussed here because, as noted by Tabachnick and Fidell (2007), as long as the group sizes are approximately equal (largest/smallest $\leq 4), \mathrm{F}$ is robust against the violation of the assumption of homogeneity of variances.

\section{The First Research Question}

The first research question of this study questioned the way EFL teachers' TA affects their TS in a systematic fashion. A one-way ANOVA was run whose results suggested that, on average, those EFL learners whose teachers enjoy a high TA level $(M=204.63)$ show a higher perception toward $T S$ than the moderate $(M=200.74)$ and low $(M=194.08)$ TA groups. 
The results of a one-way $\operatorname{ANOVA}\left(F(2,196)=3.55, p=.03<.05, \omega^{2}=.025\right.$, representing a weak to moderate effect size; Table 3) indicated statistically significant but weak to moderate differences among the mean scores of the three groups on TS. Therefore, this study failed to reject that EFL teachers' level of TA significantly affects EFL learners' perceived TS.

TABLE 3:

ONE-WAy ANOVA: TEACHING SUCCESS By LEVELS OF TEACHING AUTONOMY

\begin{tabular}{llllll}
\hline & Sum of Squares & Df & Mean Square & F & Sig. \\
\hline Between Groups & 3066.410 & 2 & 1533.205 & 3.553 & .030 \\
Within Groups & 84579.058 & 196 & 431.526 & & \\
Total & 87645.467 & 198 & & & \\
\hline
\end{tabular}

Following the results of the one-way ANOVA, the results of the post-hoc Scheffe's test, presented in Table 4, (MD $=10.54, p=.041<.01)$ indicated that there is a significant difference in the perception of EFL learners toward TS between high $(M=204.63)$ and low $(M=194.08)$ TA groups. This is to say that those EFL learners whose teachers have a high TA level hold a significantly higher perception toward EFL teachers' TS. However, the differences observed in the other two pairs of means, i.e. high vs. moderate and moderate vs. low groups, were not significant. Results are also exhibited in Figure 2.

TABLE 4:

POST-HOC SCHEFFE's TEST: TEACHING SUCCESS BY LEVELS OF TEACHING AUTONOMY

\begin{tabular}{|c|c|c|c|c|c|c|}
\hline \multirow[t]{2}{*}{ (I) Autonomy Level } & \multirow[t]{2}{*}{ (J) Autonomy Level } & \multirow{2}{*}{\multicolumn{2}{|c|}{ Mean Difference (I-J) Std. Error }} & \multirow[t]{2}{*}{ Sig. } & \multicolumn{2}{|c|}{$95 \%$ Confidence Interval } \\
\hline & & & & & Lower Bound & Upper Bound \\
\hline Moderate & Low & 6.655 & 3.408 & .151 & -1.75 & 15.06 \\
\hline \multirow{2}{*}{ High } & Low & $10.546^{*}$ & 4.136 & .041 & .34 & 20.75 \\
\hline & Moderate & 3.891 & 3.818 & .596 & -5.53 & 13.31 \\
\hline
\end{tabular}

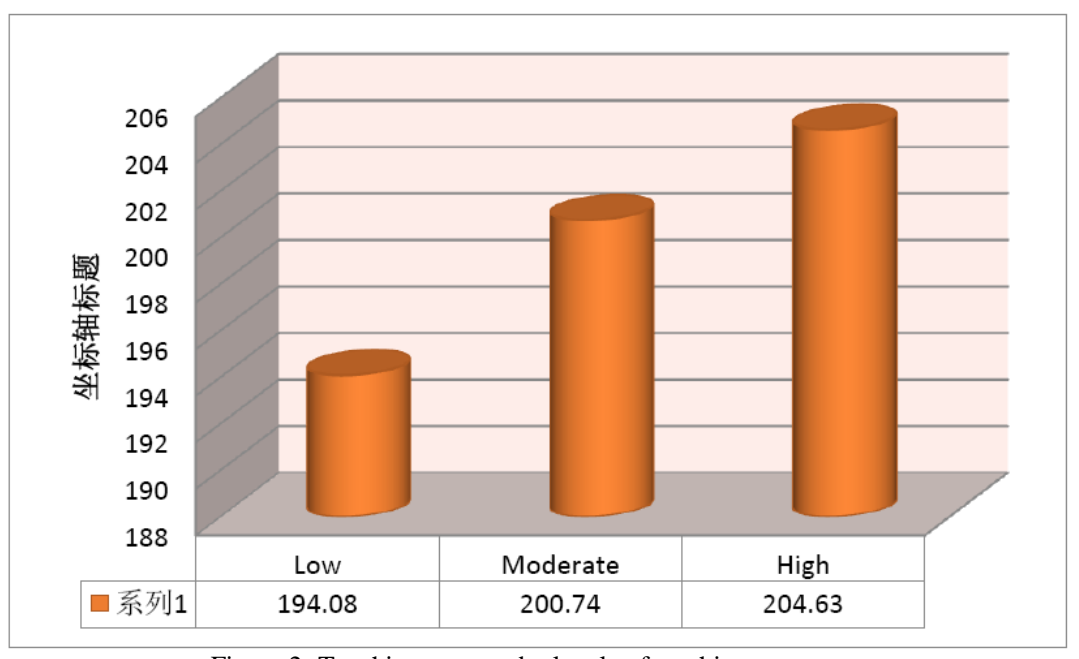

Figure 2: Teaching success by levels of teaching autonomy

\section{The Second Research Question}

The second research question of this study questioned the way EFL teachers' CT affects their TS in a systematic way. In order to answer this question, a one-way ANOVA was run whose results suggested that, on average, those EFL learners whose teachers have a low CT level $(\mathrm{M}=202.33)$ show a higher perception toward TS than the moderate $(\mathrm{M}=$ 201.10) and high $(\mathrm{M}=194.37) \mathrm{CT}$ levels.

The results of the one-way ANOVA, $F(2,196)=2.69, p=.07>.05$, (Table 5) indicated non-significant differences among the mean scores of the three CT groups on TS. Therefore, this study rejected the idea that EFL teachers' level of CT has a significant impact on EFL learners' perceived TS. Results are also exhibited in Figure 3.

TABLE 5:

ONE-WAY ANOVA TEACHING SUCCESS BY LEVELS OF CRITICAL THINKING

\begin{tabular}{llllll}
\hline & Sum of Squares & Df & Mean Square & F & Sig. \\
\hline Between Groups & 2349.329 & 2 & 1174.665 & 2.699 & .070 \\
Within Groups & 85296.138 & 196 & 435.184 & & \\
Total & 87645.467 & 198 & & & \\
\hline
\end{tabular}






Figure 3: Teaching success by levels of critical thinking

\section{The Third Research Question}

In order to investigate the way EFL teachers' TA affects EFL learners' LLS in a systematic way, a one-way ANOVA was run whose results suggested that, on average, those EFL learners whose teachers have a moderate level of TA $(\mathrm{M}=$ 128.31) show a higher use of LLS than the low $(M=123.28)$ and high $(M=123.19)$ TA groups.

The results of the one-way ANOVA, $F(2,196)=2.17, p=.11>.05$, (Table 6) indicated non-significant differences among the mean scores of the three groups on LLS. Thus, it was concluded that EFL teachers' level of TA does not have any significant effect on EFL learners' use of LLS. Results are also exhibited in Figure 4.

TABLE 6:

ONE-WAY ANOVA LANGUAGE LEARNING STRATEGIES BY LEVELS OF TEACHING AUTONOMY

\begin{tabular}{llllll}
\hline & Sum of Squares & Df & Mean Square & F & Sig. \\
\hline Between Groups & 1273.843 & 2 & 636.921 & 2.179 & .116 \\
Within Groups & 57296.921 & 196 & 292.331 & & \\
Total & 58570.764 & 198 & & & \\
\hline
\end{tabular}



Figure 4: Language learning strategies by levels of teaching autonomy

\section{The Fourth Research Question}

The fourth/last research question attempted to investigate the way EFL teachers' CT affects EFL learners' LLS use. Accordingly, a one-way ANOVA was run to investigate the effect of EFL teachers' CT level on EFL learners' use of LLS. Results suggested that, on average, EFL learners whose teachers have a high CT level $(M=127.97)$ show a higher use of LLS than the moderate $(\mathrm{M}=127.56)$ and low $(\mathrm{M}=122.26) \mathrm{CT}$ groups.

The results of the one-way ANOVA, $F(2,196)=2.43, p=.09>.05$, (Table 7) indicated non-significant differences among the mean scores of the three CT groups on LLS. Thus, it was supported that EFL teachers' level of CT does not have any significant effect on EFL learners' use of LLS. Results are also exhibited in Figure 5. 
TABLE 7:

ONE-WAy ANOVA LANGUAGE LEARNING STRATEGIES By LEVELS OF CRITICAL THINKING

\begin{tabular}{llllll}
\hline & Sum of Squares & Df & Mean Square & F & Sig. \\
\hline Between Groups & 1422.538 & 2 & 711.269 & 2.439 & .090 \\
Within Groups & 57148.226 & 196 & 291.573 & & \\
Total & 58570.764 & 198 & & & \\
\hline
\end{tabular}

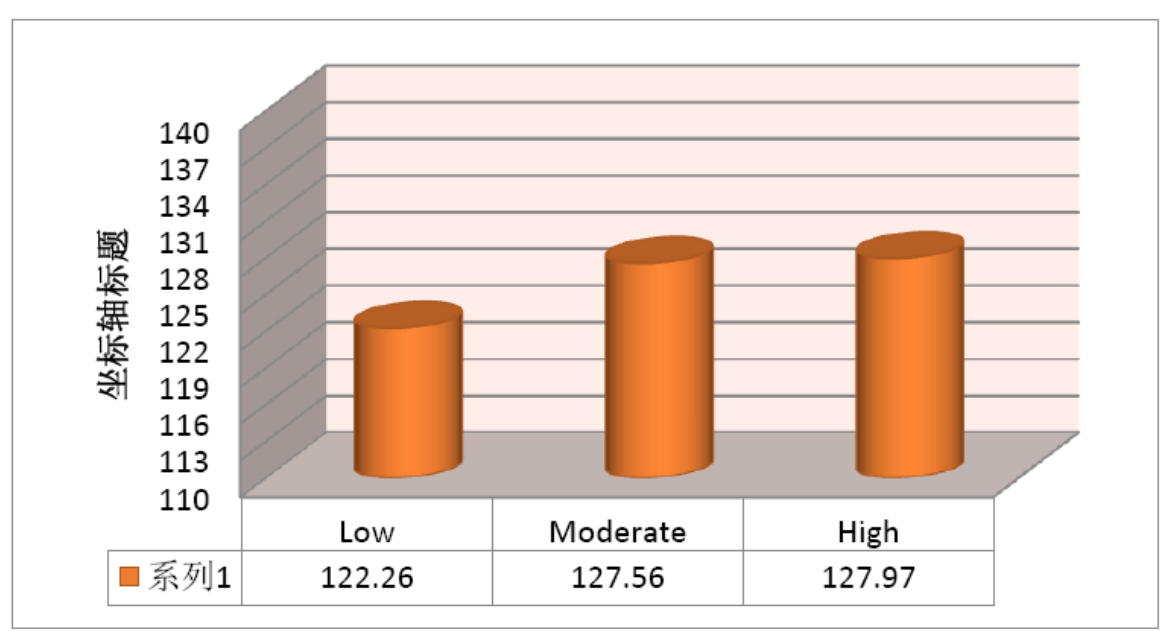

Figure 5: Language learning strategies by levels of critical thinking

\section{DISCUSSION}

Based on the points stated earlier, there is a common belief that EFL teachers' autonomous practice based on their own agency can materialize pedagogical goals in an EFL context (Farrell, 2012; Kumaravadivelu, 2012; Paul \& Elder, 2008; Scharle \& Szabo, 2000). This study evaluated the validity of this premise by studying the way EFL teachers' TA affects their TS in a systematic fashion. The results of a one-way ANOVA followed by a post-hoc Scheffe's revealed that those EFL learners whose teachers had a high TA level show a significantly higher perception toward TS. However, the weak to moderate effect size indicated statistically significant but weak to moderate differences between the mean scores of the three groups of TA on TS. As a result, although observing a statistically significant difference among TA levels regarding TS, this study failed to reject that EFL teachers' TA levels significantly affect EFL learners' perceived TS.

As reported above, the results of statistical analyses demonstrated that there is a direct relationship between EFL teachers' TA and their TS, as perceived by EFL learners. Put another way, the more an EFL teacher acts autonomously, the more successful s/he appears to be in realizing pedagogical goals. This point also confirms that TA is a feature that EFL learners value and appreciate (Farrell, 2012). This becomes obvious by recollecting the point that the questionnaire of TA was completed by EFL learners. This analysis, addressing the first research question, reported the most significant observed relationship in this study. The last point to be made is that the abovementioned weak effect size could have been larger if a larger sample pool was available (Best \& Kahn, 2006; Tabachnick \& Fidell, 2007). Therefore, the non-significant impact of TA on TS is a point whose generalizability in other contexts should be discussed with caution.

The introductory section provided evidence for the widely-held belief that EFL teachers' reflective practice and CT ability can exert profound impact on the way they succeed in achieving pedagogical goals (Borg, 2006; Farrell, 2012; Freeman, 2002). Based on this premise, the second research question of this study attempted to examine the way EFL teachers' CT affects their TS. Statistical analyses suggested that in this context, those EFL learners whose teachers enjoy a low CT level show a higher perception toward TS. This means that EFL teacher are not positively affected by EFL teachers' CT. However, this relationship did not turn out to be a significant one. Put simply, although low CT appeared to be contemporaneous with higher degree of success, this point was not confirmed by statistical analyses. One justification for observing this somehow-surprising result might be considering the fact that Iranian students are not educated as critical thinkers in their L1 educational system and that Iranian culture does not attach a high value to CT (Fahim \& Ahmadian, 2012). Therefore, it can be argued that appreciating CT as an asset for EFL teachers is a contextdependent notion.

Another premise which was questioned in this study was the stated idea that EFL teachers' autonomous practice affects and predicts the way learners learn an L2 (King, 2003; Kumaravadivelu, 2012) which includes the techniques and strategies that EFL learners employ to facilitate the learning process. Accordingly, the penultimate research question of this study attempted to systematically investigate the way EFL teachers' TA affects EFL learners' LLS. Pertinent statistical analyses suggested that in those classes where EFL teachers possess a moderate level of TA EFL learners show a higher use of LLS. In other words, neither high level of TA nor low level of TA could promote LLS 
among learners. Put another way, TA did not turn out to be a determining factor when it comes to EFL learners LLS use. This finding can be followed by two different interpretations. First, the sample pool is not large, and other studies should study this relationship. Second, TA does not directly influence the techniques EFL learners employ, and the relationship is more of an indirect nature. This result, if observed in other contexts, might increase the validity of the second interpretation.

A further driving force of this study was evaluating the idea that EFL teachers' reflectiveness and critical thinking ability can significantly affect the learning process (King, 2003; Kumaravadivelu, 2012). Knowing that LLS is a determining factor in the way L2 learners make progress in L2 (Green \& Oxford, 1995; Griffiths, 2007; O'Maley \& Chamot, 1990), the last research question of this study questioned the relationship between EFL teachers' CT levels and EFL learners' use of LLS. The obtained results suggested that EFL learners whose teachers enjoy a high CT level show a higher use of LLS than others. Notwithstanding being non-significant, this finding exhibits the tendency of observing higher levels to LLS among learners when EFL teachers possess higher levels of CT. Finally, about this finding, one statistical issue should be recalled, and it is the fact that this non-significant impact could have turned into a significant one if a larger sample pool were available (Best \& Kahn, 2006; Tabachnick \& Fidell, 2007). Therefore, the nonsignificant impact of CT on LLS is a point whose generalizability in other contexts needs confirmation in other similar studies.

There are certain points which should be considered when discussing and attempting to interpret the abovementioned findings. The main limitation imposed on the findings of this study, as briefly stated before, was the number of observed classrooms. When it comes to inspecting the way variables of a study interact, having a high number of participants would increase the chance of observing a significant relationship. This would also support and amplify the validity of the findings (Creswell, 2012; Lodico, Spaulding, \& Voegtle, 2010; Springer, 2010). Therefore, it can be argued that having a larger participant pool could have turned the non-significant relationships of this study into significant ones, i.e. the last three research questions.

Another factor which seems to have affected the findings is the number of sessions EFL teachers and EFL learners spent together. The complex and multifaceted characteristics of human being, in this case EFL learners, need higher levels of interaction, exposure, and persistence in order to be influenced by an instructor (Lightbown \& Spada, 2013). In other words, if the number of sessions could be larger, it would affect both learners and validity of the findings (Springer, 2010). Accordingly, it might be reasonable to argue that if a number higher than 15 sessions were possible, the results might have turned out to be more significant.

In this study, none of the questionnaires was administered twice. The rationale for this attempt was three-fold: a) the nature of the study and its descriptive design, b) eliminating the factor of test familiarity which would affect participants' performance on any subsequent similar test (Best \& Kahn, 2006), and c) controlling for the factor of subject mortality or losing participants. However, it seems to be well-justified to argue that being able to compare the entry and exit behavior of EFL learners, probably through an Analysis of Covariance (ANCOVA), could have provided a higher level of understanding about the way teacher characteristics have affected those of learners.

Another potential factor which might have affected the generalizability of the findings of this study is cultural factors. Cultural factors are believed to have a profound impact on learning, especially language learning (Lightbown \& Spada, 2013; Moore, 2000). Moreover, there is a unanimous consensus that different cultures approach CT and independent performance differently (Lun, Fischer, \& Ward, 2010). Therefore, different contexts and different EFL learners might adopt different perspectives on CT and TA.

\section{CONCLUSION}

Inconsistent with the conventional beliefs, it is now believed that EFL teachers function as reflective practitioners who play the role of change agents for EFL learners (Kumaravadivelu, 2012). Moreover, critically analyzing the classroom practice and acting autonomously have been introduced as the predictors of teachers' success and learners' performance (King, 2003). Based on these premises, this study set out to systematically study the effect of EFL teachers' CT and TA on their TS and EFL learners' LLS use through addressing four research questions (see the introductory section).

Both EFL teachers and EFL learners participated in this study. The results of data analysis in this ex post facto study revealed that those EFL learners whose teachers had a high TA level show a significantly higher perception toward TS. Moreover, those learners whose teachers had a low CT level showed a higher, but non-significant, perception toward TS. Furthermore, EFL learners whose teachers had a moderate level of TA demonstrated a higher, but non-significant, use of LLS. Finally, EFL learners whose teachers had a high CT level showed a higher, but non-significant use of LLS.

Based on the obtained results and considering the limitations and peculiarities of this study, the researchers came up with the following conclusions:

a) Autonomous teaching is one of the main features of successful EFL teachers (Farrell, 2012). Therefore, EFL teachers should avoid assuming their role as knowledge transmitters. Instead, context-sensitivity, following a humanistic perspective, and reasonable familiarity with all the available techniques and methods should constitute the basis for EFL teachers' practice (Bell, 2003; Kumaravadivelu, 2001). 
b) CT, although being significantly related to autonomy and teaching quality (Dewey, 1933; Nosratinia \& Zaker, 2014, 2015), is a psychological construct whose influence on individuals and teaching quality is context-bound (Fahim \& Ahmadian, 2012). Therefore, CT should be introduced to Iranian EFL learners as a means for bettering learning and functioning (Borg, 2006; Farrell, 2012; Freeman, 2002).

c) Exercising CT by EFL teachers can promote the quality and quantity of the techniques EFL learners employ for language learning. As a result, language learning will be facilitated (Nosratinia, Saveiy, \& Zaker, 2014; Oxford, 1990).

Regarding the limitations and drawing upon the findings, there are some possible avenues for future research. First, further studies may replicate this study with a larger sample size which can increase the possibility of observing significant differences among different TA and CT levels regarding TS and learners' LLS (Creswell, 2012; Lodico, Spaulding, \& Voegtle, 2010; Springer, 2010). Second, other studies can provide a higher number of instruction sessions which can affect and the way learners are influenced by the instruction (Lightbown \& Spada, 2013). Third, other researchers can compare the entry and exit behavior of EFL learners, probably through an Analysis of Covariance (ANCOVA), in order to provide a higher level of understanding about the way teacher characteristics affect EFL learners. Forth, it is suggested to inspect the way other mental and personality factors interact with the variables of this study. Fifth, this study can be replicated employing some qualitative instruments, e.g. interviews, in order to increase the validity and generalizability of the findings. Finally, it is suggested to replicate this study among other age groups.

\section{REFERENCES}

[1] Akbari, R. (2008). Transforming lives: Introducing critical pedagogy in ELT classrooms. ELT Journal 62.3, 276-283. doi: 10.1093/elt/ccn025.

[2] Bell, D. M. (2003). Method and postmethod: Are they really so incompatible? TESOL Quarterly 37. 2, 325-336. doi: $10.2307 / 3588507$.

[3] Best, J. W. \& Kahn, J. V. (2006). Research in education (10th edn.). Boston, MA: Pearson Education, Inc.

[4] Borg, S. (2006). Teacher cognition and language education: Research and practice. London: Continuum.

[5] Creswell, J. H. (2012). Educational research: Planning, conducting, and evaluating quantitative and qualitative research (4th edn.). New York: Pearson.

[6] Dewey, J. (1933). How we think. Madison, WI: University of Wisconsin Press.

[7] Edge, J. (2001). Action research. Washington, DC: TESOL.

[8] Ehrman, M. \& Oxford, R. L. (1990). Adult language learning styles and strategies in an intensive training setting. The Modern Language Journal 74.3, 311-327. doi: 10.1111/j.1540-4781.1990.tb01069.x.

[9] Elizabeth, C. L., May, C. M. \& Chee, P. K. (2008). Building a model to define the concept of teacher success in Hong Kong. Teaching and Teacher Education 24, 623-634. doi: 10.1016/j.tate.2007.09.007.

[10] Fahim, M. \& Ahmadian, M. (2012). Critical thinking and Iranian EFL context. Journal of Language Teaching and Research 3.4, 793-800. doi:10.4304/jltr.3.4.793-800.

[11] Fahim, M. \& Zaker, A. (2014). EFL learners' creativity and critical thinking: Are they associated? Humanising Language Teaching, 16(3). Retrieved March 9, 2015, from http://www.hltmag.co.uk/jun14/mart01.htm.

[12] Farrell, T.S.C. (2012). Reflective practice as professional development. In C. Coombe, L. England \& J. Schmidt (eds.), Reigniting, retooling and retiring in English language teaching. East Lancing: University of Michigan Press, 23-32.

[13] Freeman, D. (2002). The hidden side of the work: Teacher knowledge and learning to teach. A perspective from North American educational research on teacher education in English language teaching. Language Teaching 35.1, 1-13. doi: $10.1017 / \mathrm{S} 0261444801001720$.

[14] Garton, S. (2008). Teacher beliefs and interaction in the language classroom. In S. Garton \& K. Richards (eds.), Professional encounters in TESOL: Discourses of teachers in teaching. Basingstoke, Hampshire: Palgrave Macmillan, 67-86. doi: $10.1057 / 9780230594173$.

[15] Green, J. M. \& Oxford, R. L. (1995). A closer look at learning strategies, L2 proficiency, and gender. TESOL Quarterly 29.2, 261-297. doi: 10.2307/3587625.

[16] Griffiths, C. (2007). Language learning strategies: Student's and teacher's perceptions. ELT Journal 61. 2, 91-99. doi: $10.1093 / \mathrm{elt} / \mathrm{ccm} 001$.

[17] Haskvitz A. (2007). Eleven traits of a good teacher. Retrieved March 9, 2014 from http://carfamily.wordpress.com/2007/02/18/11-traits-of-a-good-teacher/.

[18] Honey, P. (2000). Critical Thinking Questionnaire. http://www.peterhoney.com/criticalthinkingquestionnaire.html (accessed $11 / 1 / 2009)$.

[19] King R., J. (2003). Teacher quality: Understanding the effectiveness of teacher attributes. Retrieved June 21, 2013 from: http://www.epi.org/publication/books_teacher_quality_execsum_intro/.

[20] Kumaravadivelu, B. (2001). Toward a postmethod pedagogy. TESOL Quarterly 35.4, 537-560. doi: 10.2307/3588427.

[21] Kumaravadivelu, B. (2008). Understanding language teaching: From method to postmethod. Mahwah, NJ: Lawrence Erlbaum.

[22] Kumaravadivelu, B. (2012). Language teacher education for a global society: A modular model for knowing, analyzing, recognizing, doing, and seeing. New York: Routledge.

[23] Lange, D. (1990). A blueprint for a teacher development program. In J. C. Richards \& D. Nunan (eds.), Second language teacher education. New York: Cambridge University Press, 245-268.

[24] Lightbown, P. \& Spada, N. (2013). How languages are learned (4th edn.). Oxford: Oxford University Press.

[25] Little, D. (1991). Learner autonomy 1: Definitions, issues and problems. Dublin: Authentik.

[26] Lodico, M., Spaulding, D. \& Voegtle, K. (2010). Methods in educational research: From theory to practice (2nd edn.). San Francisco: John Wiley \& Sons. 
[27] Lun, V. M., Fischer, R. \& Ward, C. (2010). Exploring cultural differences in critical thinking: Is it about my thinking style or the language I speak? Learning and Individual Differences 20.6, 604-616. doi: 10.1016/j.lindif.2010.07.001.

[28] Mackey, A. \& Gass, M. S. (2005). Second language research: Methodology and design. New Jersey: Lawrence Erlbaum Associates.

[29] Moafian, F. \& Pishghadam, R. (2009). Construct validation of a questionnaire on characteristics of successful EFL teachers. Pazhuhesh-e Zabanhe-ye Khareji Journal 54, 127-142.

[30] Moore, A. (2000). Teaching and learning: Pedagogy, curriculum and culture. London: Routledge Falmer.

[31] Naeini, J. (2005). The effects of collaborative learning on critical thinking of Iranian EFL learners. M.A. thesis, Islamic Azad University at Central Tehran, Iran.

[32] Nation, I. S. P. \& Macalister, J. (2010). Language curriculum design. New York: Routledge.

[33] Nosratinia, M., Abbasi, M. \& Zaker, A. (2015). Promoting second language learners' vocabulary learning strategies: Can autonomy and critical thinking make a contribution? International Journal of Applied Linguistics and English Literature 4.3, 21-30. doi:10.7575/aiac.ijalel.v.4n.3p.21.

[34] Nosratinia, M., Saveiy, M. \& Zaker, A. (2014). EFL learners' self-efficacy, metacognitive awareness, and use of language learning strategies: How are they associated? Theory and Practice in Language Studies 4.5, 1080-1092. doi: 10.4304/tpls.4.5.1080-1092.

[35] Nosratinia, M., Shakoori, N. \& Zaker, A. (2013). Language learners' internal factors and practical applications: A case of vocabulary learning strategies. IOSR Journal of Humanities and Social Science 17.1, 100-115. doi: 10.9790/0837-171100115.

[36] Nosratinia, M. \& Zaker, A. (2013, August). Autonomous learning and critical thinking: Inspecting the association among EFL learners. Paper presented at the First National Conference on Teaching English, Literature, and Translation, Shiraz University, Shiraz, Iran. Retrieved April 21, 2014, from http://www.civilica.com/Paper-TELT01-TELT01_226.html.

[37] Nosratinia, M. \& Zaker, A. (2014). Metacognitive attributes and liberated progress: The association among second language learners' critical thinking, creativity, and autonomy. SAGE Open 4.3, 1-10. doi: 10.1177/2158244014547178.

[38] Nosratinia, M. \& Zaker, A. (2015). Boosting autonomous foreign language learning: Scrutinizing the role of creativity, critical thinking, and vocabulary learning strategies. International Journal of Applied Linguistics and English Literature 4.4, 86-97. doi: 10.7575/aiac.ijalel.v.4n.4p.86.

[39] Nosratinia, M., Zaker, A. \& Saveiy, M. (2015). Higher-order thinking and individualized learning: Metacognitive awareness and self-efficacy among EFL learners. The Iranian EFL Journal 11.1, 189-207.

[40] O'Maley, J. \& Chamot, A. (1990). Learning strategies in second language acquisition. Cambridge: Cambridge University Press. doi: 10.1017/CBO9781139524490.

[41] Oxford, R. L. (1990). Language learning strategies: What every teacher should know. Boston: Heinle \& Heinle.

[42] Oxford, R. L. (1996). Learning strategies around the world: Cross-cultural perspectives. Honolulu: University of Hawaii Press.

[43] Paul, R. \& Elder, L. (2008). The miniature guide to critical thinking concepts and tools. Retrieved March 9, 2015, from https://www.criticalthinking.org/files/Concepts_Tools.pdf.

[44] Pearson, L. C. \& Hall, B. C., (1993). Initial construct validation of the teaching autonomy scale. Journal of Educational Research 86, 172-177. doi: 10.1080/00220671.1993.9941155.

[45] Richards, J. C. \& Lockhart, C. (1994). Reflective teaching. New York: Cambridge University Press.

[46] Scharle, A. \& Szabó, A. (2000). Learner autonomy: A guide to developing learner responsibility. Cambridge: Cambridge University Press.

[47] Springer, K. (2010). Educational research: A contextual approach. Hoboken, NJ: Wiley.

[48] Tabachnick, B. G. \& Fidell, L. S. (2007). Using multivariate statistics. Boston, MA: Pearson Education, Inc.

[49] Tamblyn, P. (2000). Qualities of success: Lessons from a teacher career. Education Canada 40.1, 16-19.

[50] Wenden, A. (1991). What do second-language learners know about their language learning? Applied Linguistics 7, 186-205. doi: 10.1093/applin/7.2.186.

[51] Zaker, A. (2013). The relationship among EFL learners' creativity, critical thinking, and autonomy. M.A. thesis, Islamic Azad University at Central Tehran, Iran.

[52] Zaker, A. (2015). EFL learners' language learning strategies and autonomous learning: Which one is a better predictor of L2 skills? Journal of Applied Linguistics-Dubai 1.1, 27-39.

[53] Zaker, A. (2016). Social constructivism and metacognition in an EFL context: Inspecting the contribution of critical thinking to EFL learners' social intelligence. Humanising Language Teaching 18.6. Retrieved December 27, 2016, from www.hltmag.co.uk/dec16/index.htm.

Mania Nosratinia is Assistant Professor in TEFL at Islamic Azad University at Central Tehran. She has been teaching at undergraduate and graduate levels in the areas of English language teaching methodology, language testing, and research methodology in language studies. She has published in national and international academic journals and presented in several national and international seminars.

Alireza Zaker is currently a Ph.D. student of TEFL, Islamic Azad University (IAU), Science and Research Branch, Tehran, and an active member of the Young Researchers and Elites Club, IAU. Over the past few years, he has been teaching Advanced Research, Language Assessment, Language Teaching Methodology, Language Learning Theories, and Practical Teaching courses at IAU and some state universities in Iran. 